\title{
“ANALYSIS OF RC FRAMED STRUCTURES WITH CENTRAL AND PARTIAL OPENINGS IN MASONRY INFILL WALL USING DIAGONAL STRUT METHOD”
}

\author{
Chidananda HR $^{1}$, Raghu $K^{2}$, G Narayana ${ }^{3}$ \\ ${ }^{1}$ Post graduate student, Dept of Civil Engineering, SJCIT, Chickballapura, Karnataka, India \\ ${ }^{2}$ Assistant professor, Dept of Civil Engineering, SJCIT, Chickballapura, Karnataka, India \\ ${ }^{3}$ Head of the department, Dept of Civil Engineering, SJCIT, Chickballapura, Karnataka, India
}

\begin{abstract}
In Reinforced concrete frames the masonry infill walls are a common practice in countries like India, where the region is prone to seismic activity. In general, the masonry infill walls are treated as nonstructural element in structural analysis and only the contribution of its mass for is considered and it's structural parameters like strength and stiffness is generally ignored in practice, such an approach may lead to an unsafe design. Infill walls resist lateral loads but because of the openings in the infill wall the resistance may slightly reduce. The IS code provisions do not provide guidelines for the analysis and design of RC frames with infill wall and for different percentage of openings. In this study, an office or residential building outer side central opening or outer side partial openings are used and analysis is carried for Bare Frame model, infill walls without opening, infill walls with outer periphery central opening and infill wall with outer periphery partial opening models. In ETABS software G+14 RC framed building models has been prepared, Equivalent Static Lateral force method, Response spectrum method has been performed for analysis as per IS 1893 : 2002 including p-delta effects. Storey displacement, Storey shear, Storey drift, with soft storey considering the effects of infill wall with central and partial openings are the parameters considered in this study. For modeling, the Equivalent diagonal strut method has been used to find out the width of Strut using FEMA 273 .The results for bare frame, infill wall, and infill wall with central and partial openings are discussed and conclusions are made.
\end{abstract}

Keywords: Equivalent diagonal strut, stiffness, Drift limitation.

\section{INTRODUCTION}

Earthquake is responsible for the ground motion in all directions, inducing the inertial forces on the structures. Thus the structure has to withstand lateral loads due to earthquake, wind loads along with the gravity loads. Nowadays RC frames are the common construction practice. The gap created between the columns, beams are filled by infill materials like bricks. Due to functional requirements the openings are provided in wall for windows, doors etc.,

In RC buildings the gravity loads do not cause effect, but the lateral loads like wind, earthquake tremors are a matter of great concern and need special design consideration. These lateral loads create critical stress in a building, causing lateral sway and can reach a stage of causing discomfort for the occupants.

The presence of infill walls increases the lateral stiffness, strength and reduces the fundamental period. The presence of openings in the infill walls can reduce some amount in the increase of lateral stiffness due to infill wall.

The behavior of the infill walls subjected to the lateral loads is represented as shown in fig 1 . When the lateral loads are applied the infill walls resists to some extent creating gaps at the corners as shown.
If the openings provided in the infill walls are small, its effect may be negligible in stiffness calculation. If the openings are large, it may interfere the diagonal bracing action (fig 2), thereby causing premature shear failure.

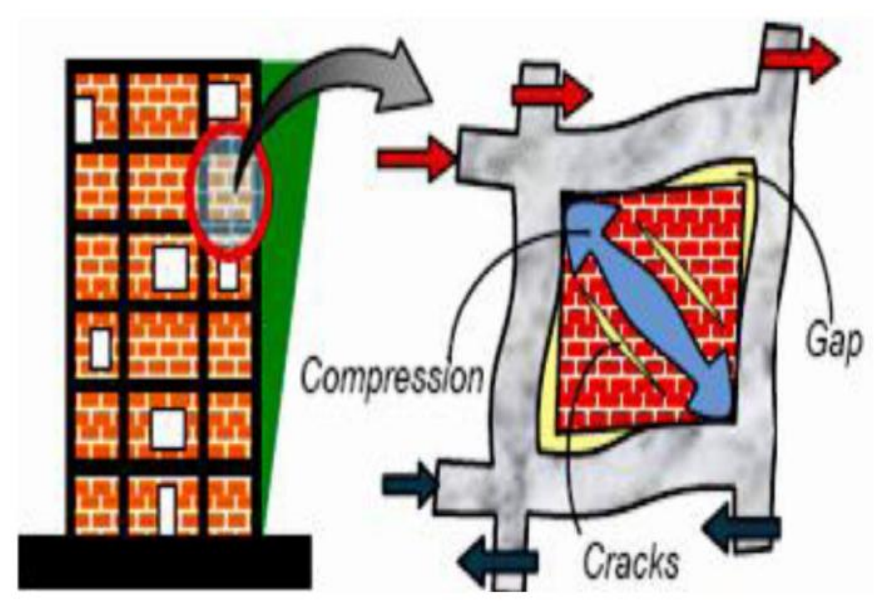

Fig -1: Behavior of the infill wall as a strut member. 

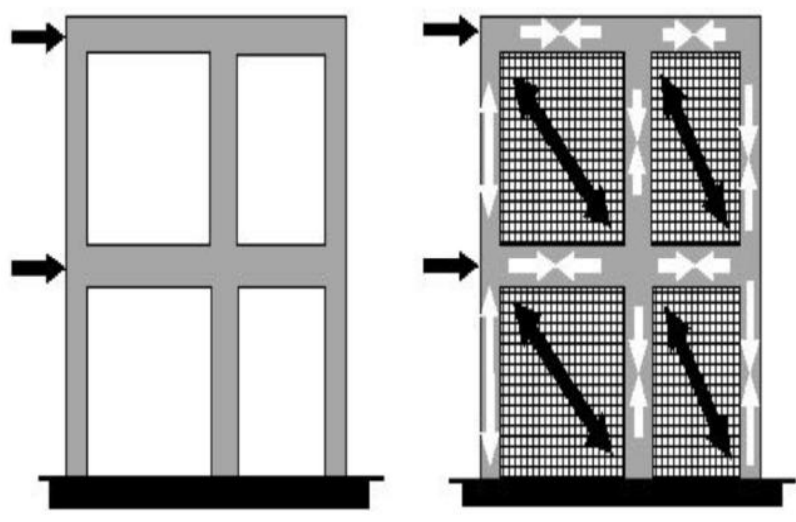

Fig -2: Bracing action of the infill wall

\subsection{Types of Infill Provisions}

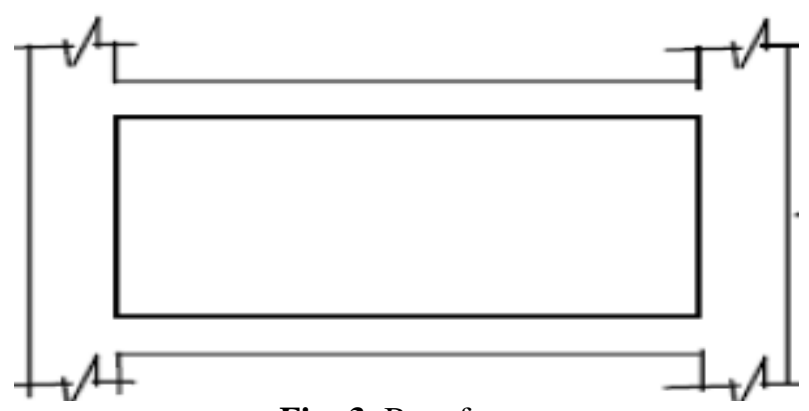

Fig -3: Bare frame

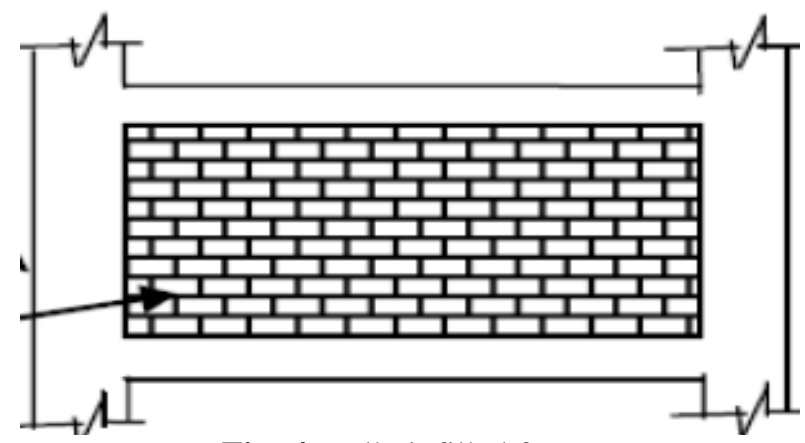

Fig -4: Fully infilled frame

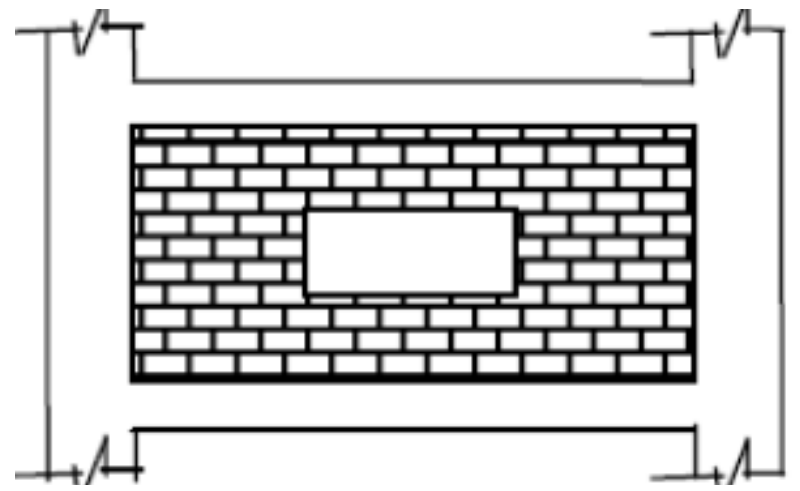

Fig -5: Infilled frame with central opening

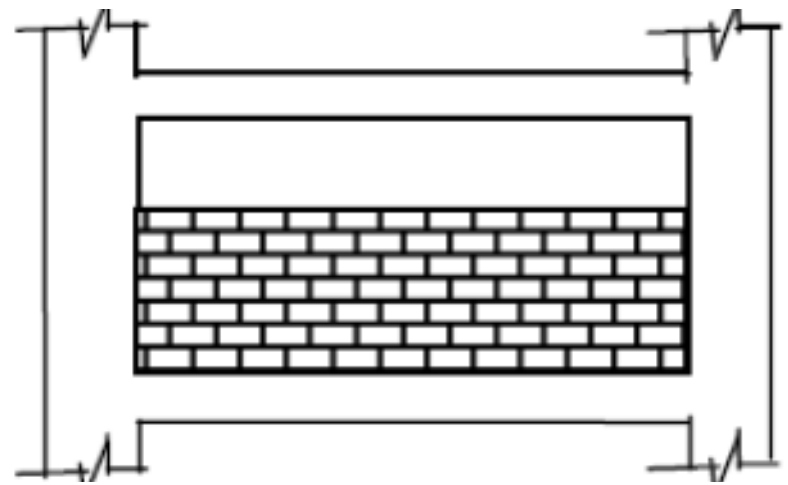

Fig -6: Partially infilled frame

The infill walls are provided in different manner as shown in Fig 3, 4, 5, 6 .

\section{LITERATURE REVIEW}

Many Researchers have developed equations for calculating the "Equivalent Diagonal Strut width". Some of the major are:

1. In 1961 Holmes,

$\mathrm{W}=\frac{\mathrm{dz}}{3}$ where, $\mathrm{dz}=$ Diagonal length of infill panel

2. In 1962 Smith,

$$
\begin{gathered}
\mathrm{W}=\sqrt{\alpha_{\mathrm{H}}^{2}+\alpha_{\mathrm{L}}^{2}} \\
\frac{\alpha_{\mathrm{h}}}{\mathrm{L}^{\prime}}=\frac{\pi}{2} \cdot \frac{1}{\lambda_{\mathrm{h}} \mathrm{L}^{\prime}} \\
\lambda_{\mathrm{h} . \mathrm{L}^{\prime}}=\mathrm{L}^{\prime} \sqrt{\frac{\mathrm{E}_{\text {panel. } \mathrm{t} \sin 2 \theta}}{4 \cdot \mathrm{E}_{\mathrm{p}} \mathrm{I}_{\mathrm{p}} \cdot \mathrm{h}}} \\
\frac{\alpha_{\mathrm{L}}}{\mathrm{L}^{\prime}}=\pi \cdot \frac{1}{\lambda_{\mathrm{l}} \mathrm{L}^{\prime}} \\
\lambda_{\mathrm{L} . \mathrm{L}^{\prime}}=\mathrm{L}^{\prime} \sqrt{\frac{\mathrm{E}_{\mathrm{panel} . \mathrm{t} \sin 2 \theta}}{4 . \mathrm{E}_{\mathrm{p}} \mathrm{I}_{\mathrm{b}} \cdot \mathrm{L}}}
\end{gathered}
$$

3. In 1969 Smith and Carter,

$$
\mathrm{W}=0.58\left(\frac{1}{\mathrm{H}}\right)^{-0.445}\left(\lambda_{\mathrm{h}} \mathrm{H}^{\prime}\right)^{0.335 \mathrm{dz}(\mathrm{x})}
$$

where $\mathrm{x}=\left(\frac{1}{H}\right)^{0.064}$ 
$\lambda_{\mathrm{h}}=\sqrt[4]{\frac{\mathrm{Ets}_{\mathrm{s}} \sin 2 \theta}{4 \mathrm{E}_{\mathrm{h}} \mathrm{H}}}$

4. In 1971 Mainstone,

$$
\mathrm{W}=0.175 \mathrm{dz}\left(\lambda_{\mathrm{h}} \mathrm{H}\right)^{-0.4}
$$

5. In 1984 Liaw and Kwan,

$$
\mathrm{W}=\frac{(0.95 \mathrm{H} \cos \theta)}{\sqrt{\lambda_{\mathrm{h}} \mathrm{H}}}
$$

6. In 1992 Paulay and Priestley,

$$
\mathrm{W}=\frac{\mathrm{dz}}{4}
$$

7. In 2009 Chethan.K,

$$
\mathrm{W}=1.414 \alpha_{\mathrm{h}},
$$

$$
\alpha_{\mathrm{h}}=\frac{\pi}{2 \lambda} \quad \lambda=\sqrt[4]{\frac{\mathrm{E}_{\mathrm{m}} \mathrm{t} \sin 2 \theta}{4 \mathrm{E}_{\mathrm{c}} \mathrm{Ih}}}
$$

\section{METHOD OF ANALYSIS OF THE INFILL}

WALL

\subsection{Data Taken}

\begin{tabular}{|l|l|}
\hline Storey & G+14 (6X4 BAYS) \\
\hline Typical storey height & $3.5 \mathrm{~m}$ \\
\hline Beam size & $400 \mathrm{X} 500 \mathrm{~mm}$ \\
\hline Column size & $600 \mathrm{X} 600 \mathrm{~mm}$ \\
\hline Live load & $3.5 \mathrm{KN} / \mathrm{m}^{2}$ \\
\hline Floor finish & $0.6 \mathrm{KN} / \mathrm{m}^{2}$ \\
\hline Water proof on terrace load & $1.5 \mathrm{KN} / \mathrm{m}^{2}$ \\
\hline Response reduction factor & 5 \\
\hline Type of soil & Medium \\
\hline Damping factor & $5 \%$ \\
\hline Grade of concrete & $\mathrm{M} 30$ \\
\hline Steel & $\mathrm{Fe} 500$ \\
\hline Density of concrete & $25 \mathrm{KN} / \mathrm{m}^{3}$ \\
\hline Density of brick infill & $20 \mathrm{KN} / \mathrm{m}^{3}$ \\
\hline Poisson's ratio of concrete & 0.2 \\
\hline Poisson's ratio of brick infill & 0.15 \\
\hline $\begin{array}{l}\text { Modulus of elasticity of } \\
\text { concrete }\end{array}$ & $22360.67 \mathrm{KN} / \mathrm{m}^{2}$ \\
\hline $\begin{array}{l}\text { Modulus of elasticity of brick } \\
\text { infill }\end{array}$ & $4000 \mathrm{KN} / \mathrm{m}^{2}$ \\
\hline Thickness of slab & $150 \mathrm{~mm}$ \\
\hline Thickness of wall & $230 \mathrm{~mm}$ \\
\hline Seismic zone & $\mathrm{V}$ \\
\hline Wind speed & $50 \mathrm{~m} / \mathrm{s}$ \\
\hline Terrain category & 2 \\
\hline Structure class & $\mathrm{C}$ \\
\hline
\end{tabular}

\subsection{Types of Model}

\begin{tabular}{|l|l|}
\hline ID & Description \\
\hline BFGSS0\% & $\begin{array}{l}\text { Bare frame with ground soft } \\
\text { storey without opening. }\end{array}$ \\
\hline BFGSS30\% & $\begin{array}{l}\text { Bare frame with ground soft } \\
\text { storey with 30\% opening. } \\
\text { BFGSS60\% } \\
\text { Bare frame with ground soft } \\
\text { storey with 60\% opening. }\end{array}$ \\
\hline SFGSSC0\% & $\begin{array}{l}\text { Strut frame with ground soft } \\
\text { storey without opening. }\end{array}$ \\
\hline SFGSSC60\% & $\begin{array}{l}\text { Strut frame with ground soft } \\
\text { storey with 30\% central } \\
\text { opening. }\end{array}$ \\
\hline SFGSSP30\% & $\begin{array}{l}\text { Strut frame with ground soft } \\
\text { storey with 60\% central } \\
\text { opening. }\end{array}$ \\
\hline SFGSSP60\% & $\begin{array}{l}\text { Strut frame with ground soft } \\
\text { storey with 30\% partial } \\
\text { opening. }\end{array}$ \\
\hline & $\begin{array}{l}\text { Strut frame with ground soft } \\
\text { storey with 60\% partial } \\
\text { opening. }\end{array}$ \\
\hline
\end{tabular}

\subsection{Modeling of Infill Wall}

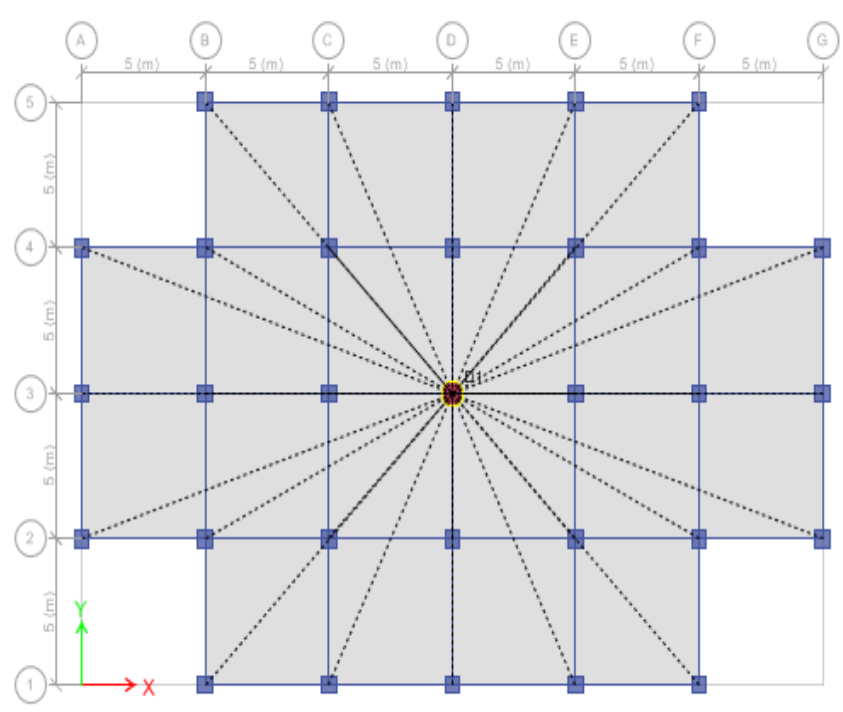

Fig -6: Plan view of the model 

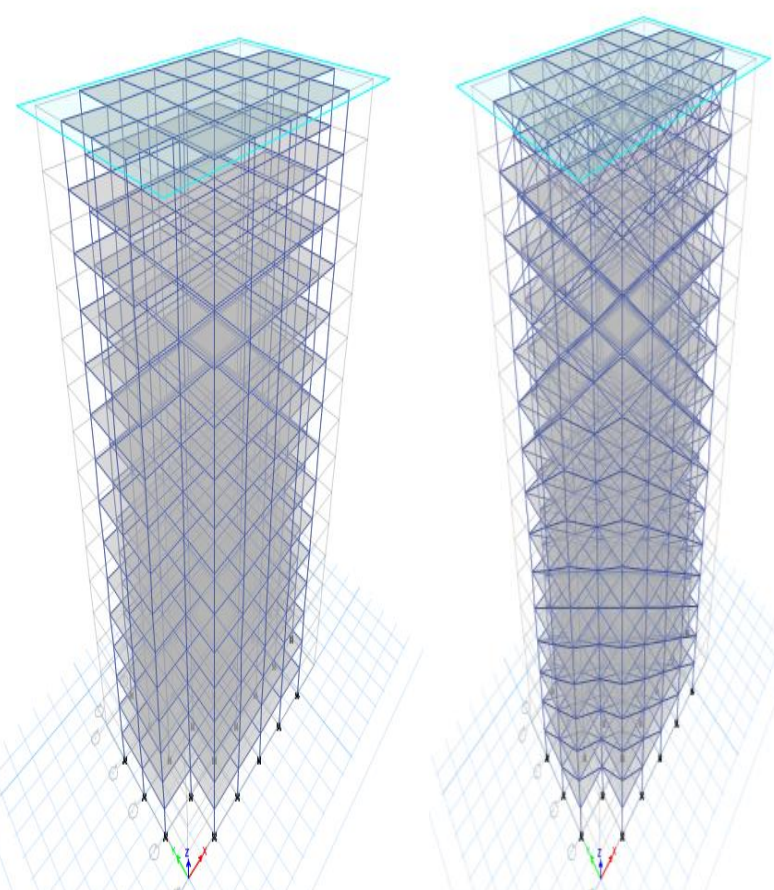

Fig -7: Elevation view of Bare frame and Strut frame

\subsection{FEMA Approach}

In the case of an infill wall located in a lateral load resisting frame the stiffness and strength contribution of the infill are considered by modeling the infill as an equivalent compression strut. Because of its simplicity, several investigators have recommended the equivalent strut concept. According to FEMA 273, infills are assumed as an equivalent diagonal strut with pin joint at the corners as shown Fig 8.

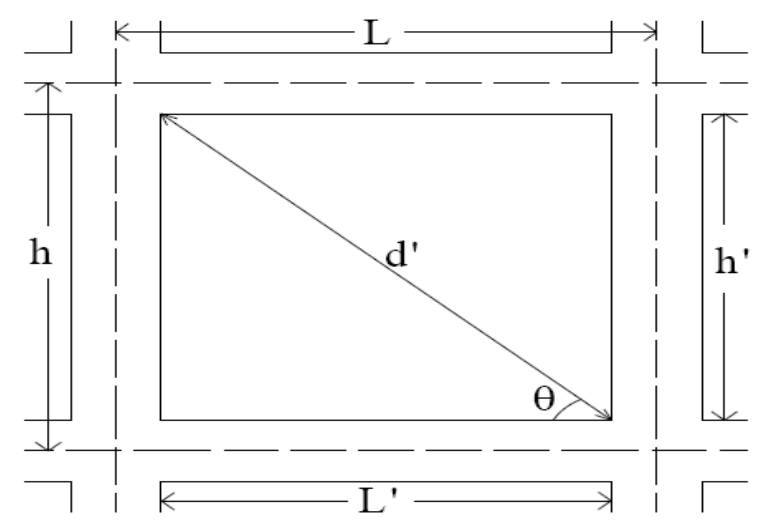

Fig -8: Equivalent diagonal strut for the infill panel

$$
\mathrm{W}=0.175\left[\lambda^{\prime} \mathrm{h}\right]^{-0.4} \mathrm{~d}^{\prime}
$$

Where, $\lambda=\sqrt[4]{(E i T S i n 2 \theta) /\left(4 E f I c H^{\prime}\right)}$

$\mathrm{T}=$ thickness of wall

$\mathrm{Ei}=$ Elasticity of concrete

$\mathrm{Ef}=$ Elasticity of brick infill

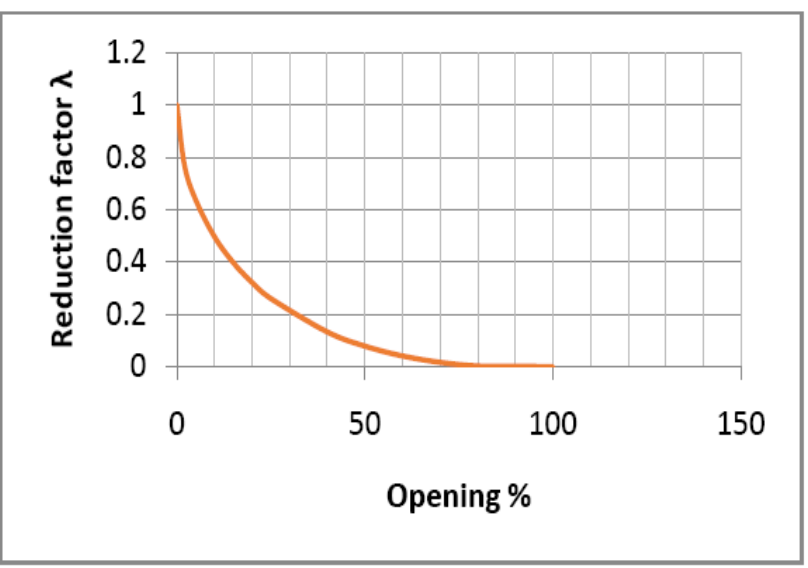

Fig -8: Reduction factor curve

Reduction factor $=1-2 \alpha_{\mathrm{w}}{ }^{0.54}+\alpha_{\mathrm{w}}{ }^{1.14}$

Opening Percentage $(\%)=\frac{\text { Area of opening }\left(\mathrm{A}_{\mathrm{op}}\right)}{\text { Area of the infill }\left(\mathrm{A}_{\text {infill }}\right)}$

\section{RESULT AND DISCUSSION}

\subsection{Displacement:}

Table -1: Displacement in $X$ direction

\begin{tabular}{|l|l|l|l|}
\hline & EQ & RS & Wind \\
\hline BFGSS0\% & 62.5 & 48.8 & 30.8 \\
\hline BFGSS30\% & 59.8 & 41.7 & 30.6 \\
\hline BFGSS60\% & 55.8 & 38.9 & 30.6 \\
\hline SFGSSC0\% & 32.4 & 23.9 & 7.4 \\
\hline SFGSSC30\% & 34.6 & 24.9 & 8.7 \\
\hline SFGSSC60\% & 35.5 & 25.5 & 9.1 \\
\hline SFGSSP30\% & 33.4 & 24.2 & 7.9 \\
\hline SFGSSP60\% & 32.8 & 24.6 & 8.4 \\
\hline
\end{tabular}

Table -2: Displacement in Y direction

\begin{tabular}{|l|l|l|l|}
\hline & EQ & RS & Wind \\
\hline BFGSS0\% & 66.3 & 51.3 & 50.8 \\
\hline BFGSS30\% & 63.4 & 44.2 & 50.8 \\
\hline BFGSS60\% & 59.1 & 41 & 50.8 \\
\hline SFGSSC0\% & 37.6 & 27.7 & 13.8 \\
\hline SFGSSC30\% & 37.9 & 27.9 & 14.6 \\
\hline SFGSSC60\% & 38 & 28.3 & 14.8 \\
\hline SFGSSP30\% & 37.8 & 27.8 & 13.9 \\
\hline SFGSSP60\% & 37.9 & 27.9 & 14.2 \\
\hline
\end{tabular}

The displacements values for different models as shown in table 1 and table 2 . The displacement is reduced by $51 \%$ from the bare frame model to the infilled frame model. But when we consider the infilled frame with central opening and partial opening $40-45 \%$ of the displacement is reduced. 


\subsection{Storey Drift:}

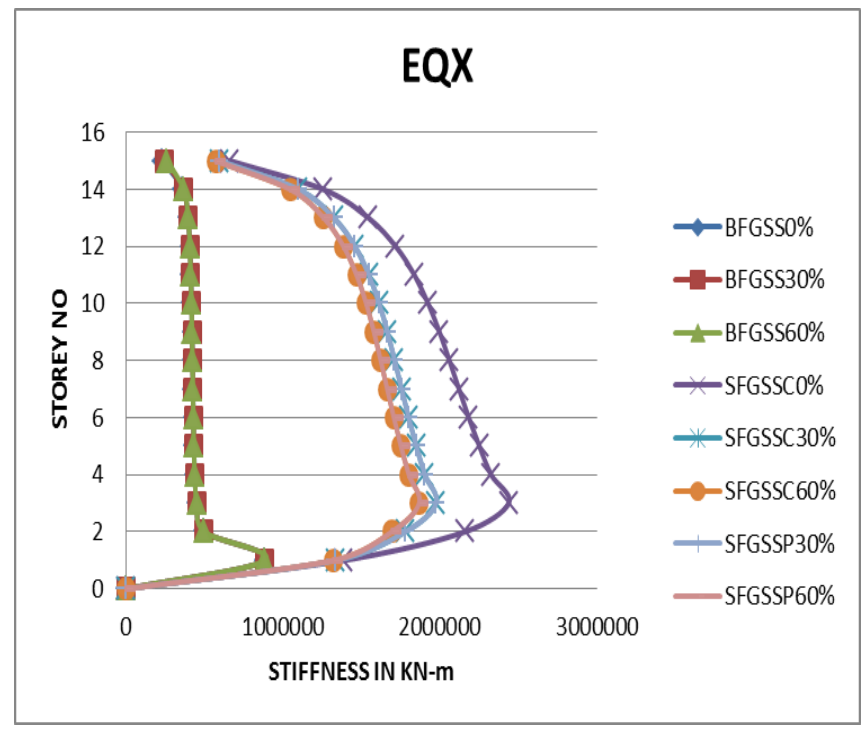

Chart -1: storey drift in $\mathrm{X}$ direction

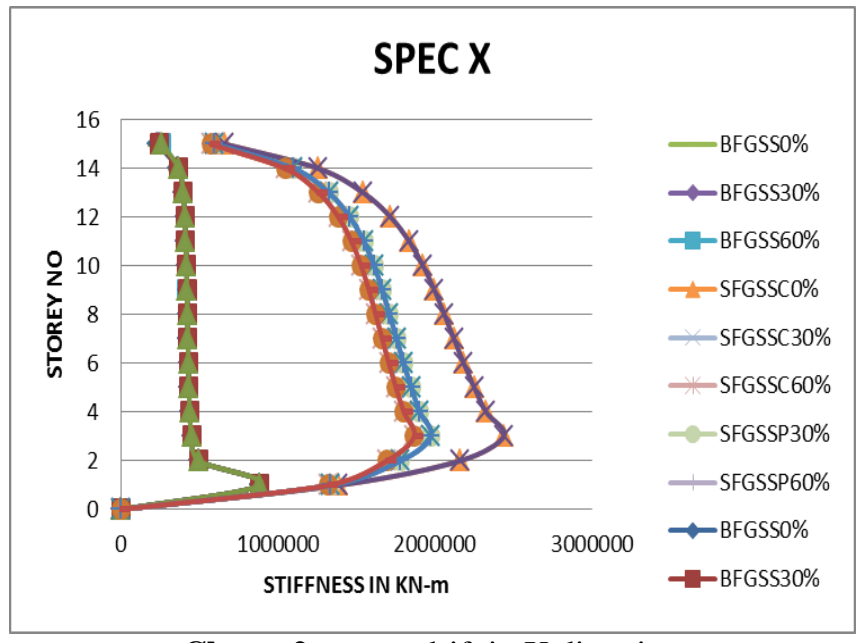

Chart -2: storey drift in $\mathrm{X}$ direction

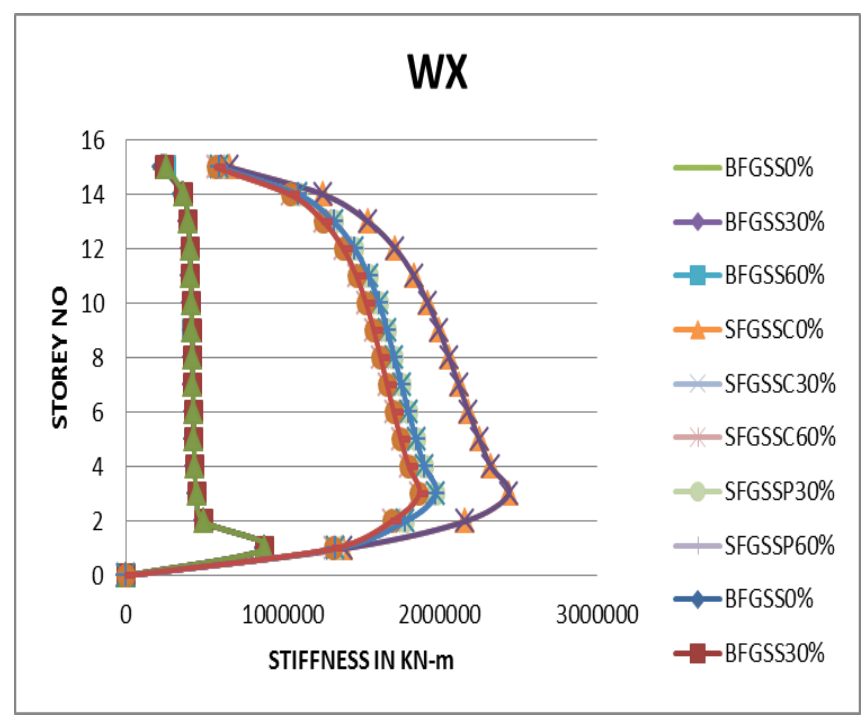

Chart -3: storey drift in $\mathrm{X}$ direction

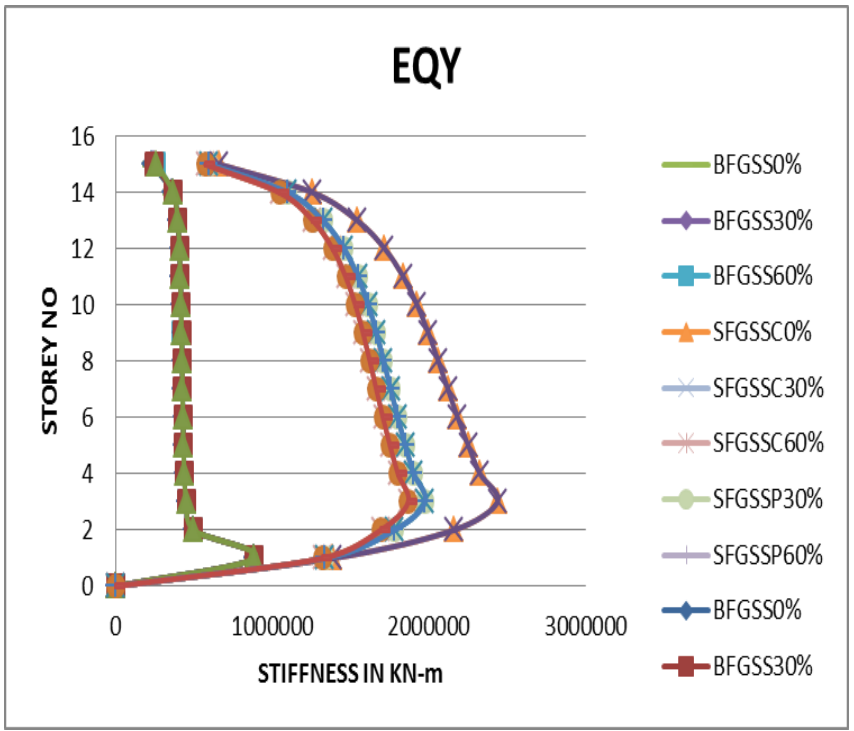

Chart -4: storey drift in Y direction

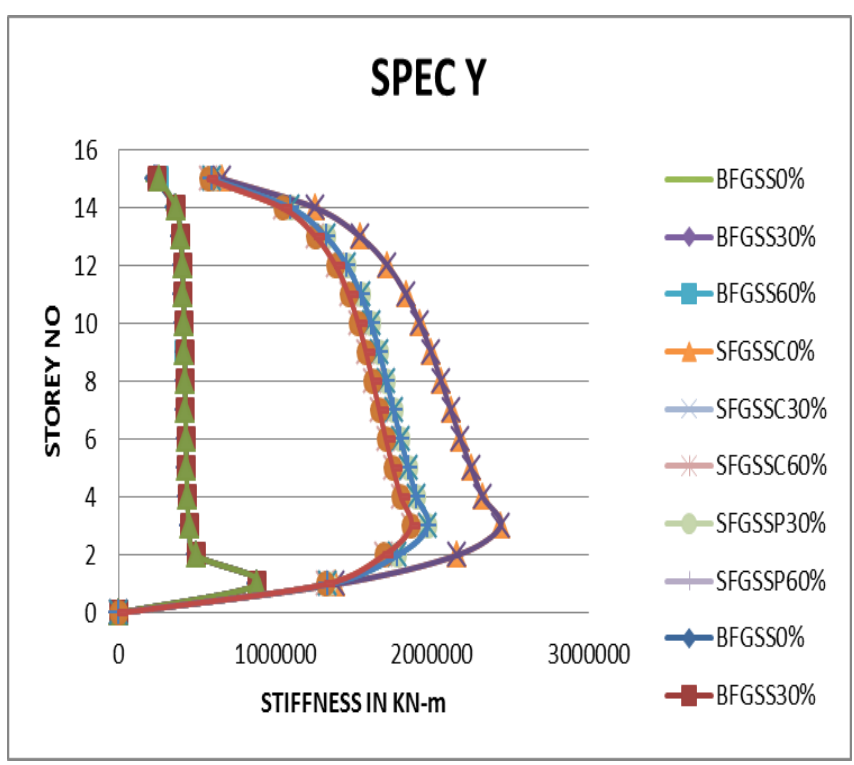

Chart -5: storey drift in Y direction

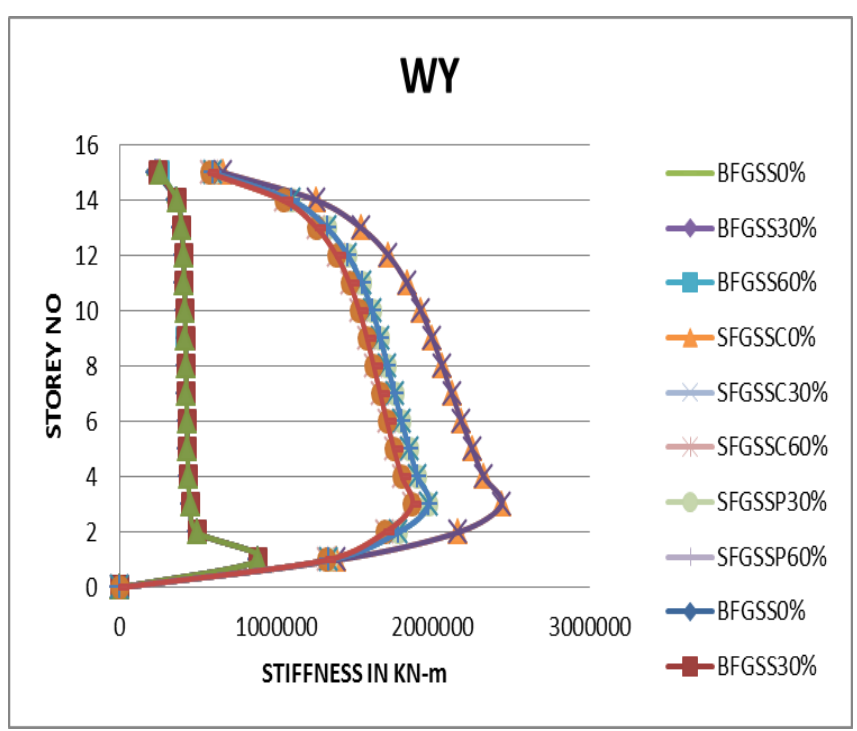

Chart -6: storey drift in Y direction 
The storey drift versus storey no is ploted for Equivalent static method, response spectrum method. wind analysis as shown in chart 1 to chart 6.The storey drift for the first storey is higher because of the open ground storey. The drift are within the limitation specified in IS 1893:2002.( ie. 0.004 times storey height)

\subsection{Stiffness:}

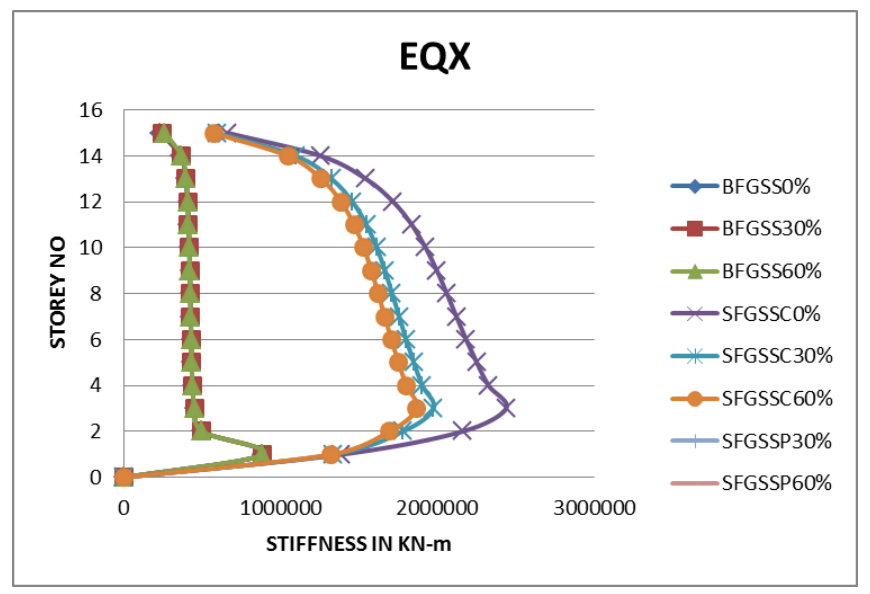

Chart -7: Stiffness in X direction

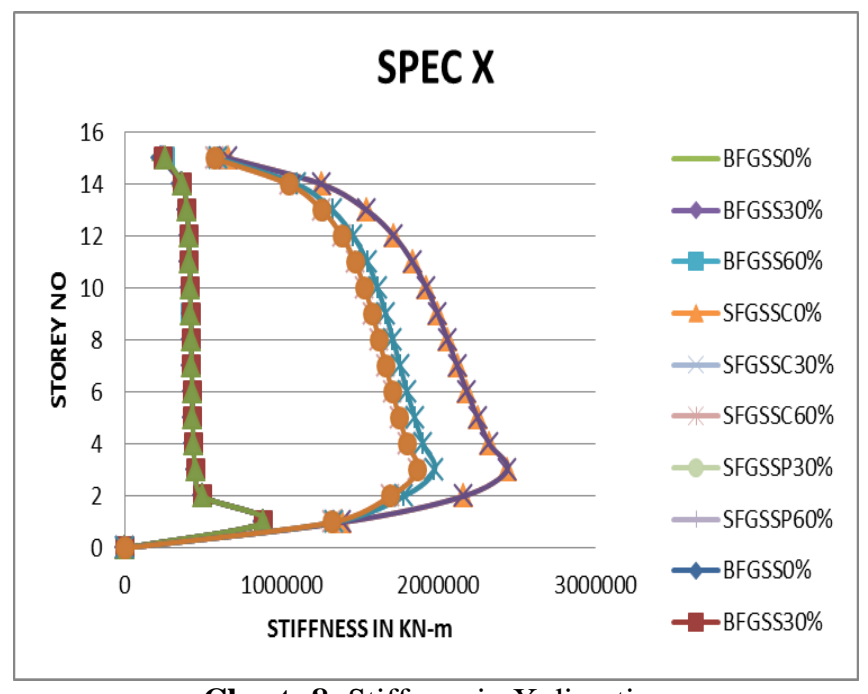

Chart -8: Stiffness in X direction

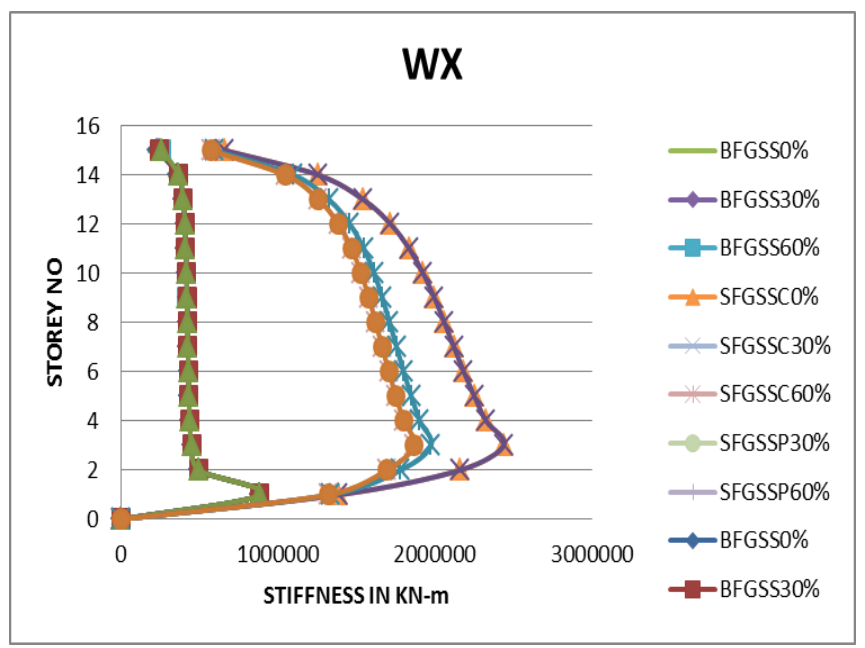

Chart -9: Stiffness in X direction

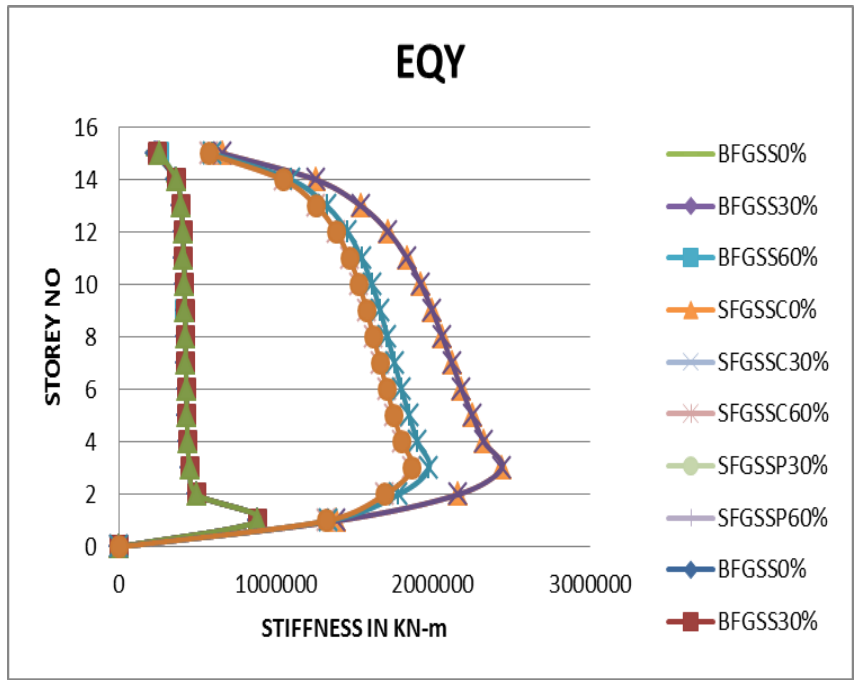

Chart -10: Stiffness in $\mathrm{X}$ direction

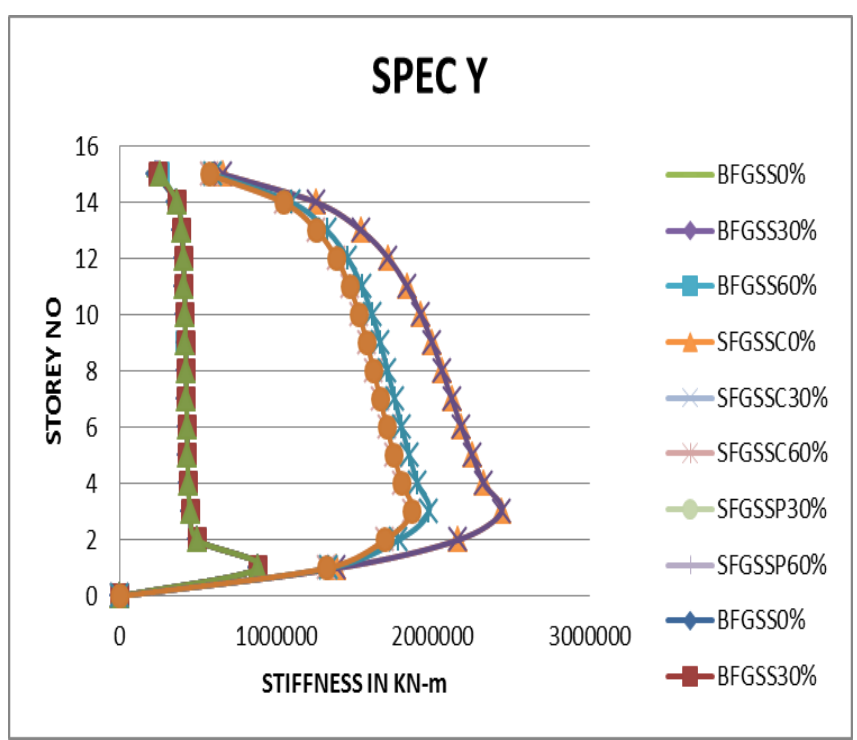

Chart -11: Stiffness in Y direction

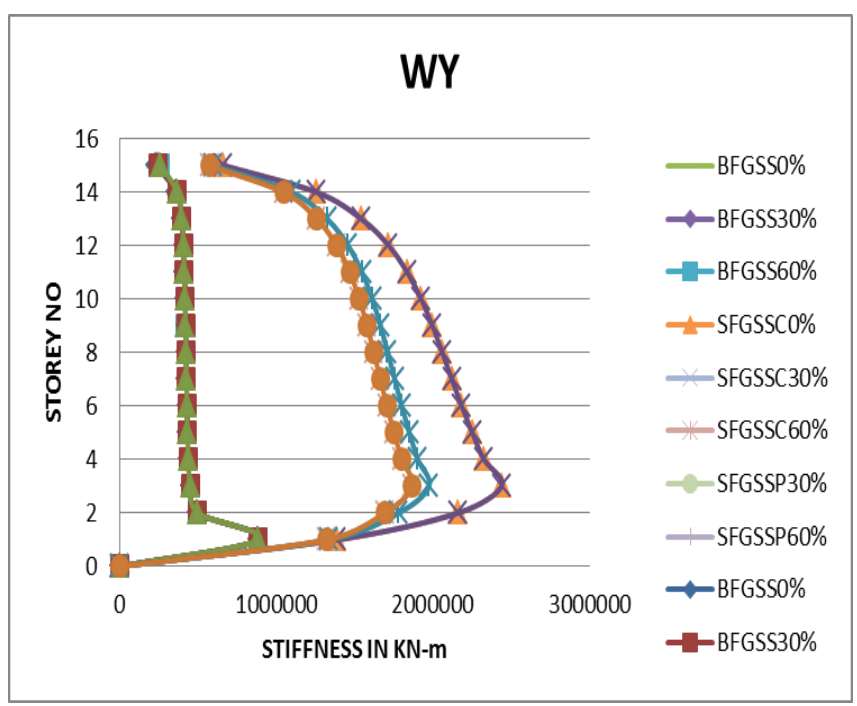

Chart -12: Stiffness in Y direction 
The stiffness for different models as shown in Chart 7 to Chart 12 . The stiffness is increased by $68 \%$ by considering the effect of infill walls and about $10 \%$ reduction due to the opening has been observed.

\subsection{Time Period:}

Table -3: Time period

\begin{tabular}{|rrrrrrr|}
\hline mode no & BFGSS0\% & BFGSS30\% & BFGSS60\% & \multicolumn{2}{l}{ SFGSSCO\% } & \multicolumn{3}{l}{ SFGSSC30\% } & SFGSSC60\% \\
1 & 2.852 & 2.73 & 2.55 & 1.537 & 1.572 & 1.606 \\
2 & 2.725 & 2.608 & 2.436 & 1.408 & 1.514 & 1.582 \\
3 & 2.492 & 2.381 & 2.217 & 1.25 & 1.491 & 1.539 \\
4 & 0.927 & 0.887 & 0.829 & 0.504 & 0.516 & 0.531 \\
5 & 0.889 & 0.851 & 0.795 & 0.467 & 0.5 & 0.52 \\
6 & 0.815 & 0.779 & 0.726 & 0.414 & 0.496 & 0.51 \\
7 & 0.527 & 0.504 & 0.471 & 0.272 & 0.29 & 0.308 \\
8 & 0.511 & 0.489 & 0.457 & 0.26 & 0.283 & 0.288 \\
9 & 0.472 & 0.451 & 0.42 & 0.243 & 0.28 & 0.284 \\
10 & 0.359 & 0.344 & 0.322 & 0.19 & 0.205 & 0.216 \\
11 & 0.349 & 0.335 & 0.313 & 0.182 & 0.198 & 0.202 \\
12 & 0.323 & 0.309 & 0.288 & 0.172 & 0.196 & 0.198 \\
13 & 0.265 & 0.254 & 0.237 & 0.145 & 0.157 & 0.165 \\
14 & 0.259 & 0.248 & 0.232 & 0.139 & 0.151 & 0.155 \\
15 & 0.239 & 0.229 & 0.213 & 0.132 & 0.15 & 0.151 \\
\hline
\end{tabular}

The time period for different models is as shown in table 3 . The time period is found to be decreased by $46 \%$ from bare frame model to infilled frame model. Because of the presence of the opening the time period has slightly incresed compared to infilled frame model.

\section{CONCLUSION}

In this paper bare frame, infilled frame models with and without opening are prtepared for linear static analysis and response spectrum analysis. The p-delta effect also been analysed but the result showed a negligible amount of variations, in that time period has significant changes. From this analysis, it shows thast p-delta effect can be considered for higher storey buildings. The displacement values shows that there is a significant decrease in displacement by considering the effect of infills and slight increase in displacement due to openings.

The stiffness is increased by about $70 \%$ by considering the effect of infills. The base shear was alson found to be incresed. It can also be concluded that, the increase in percentage of opening leads to decrease in the lateral stiffness.

\section{ACKNOWLEDGEMENTS}

I am thankful to my guide Mr. Raghu K and Dr. G Narayana for their guidance and also thankful to department civil engineering S J C Institute of technology, chickaballapur. Thanks to my dear friends who have supported me to complete this work.

\section{REFERENCES}

[1].. “Analysis Of RC Frame With and Without Masonry Infill Wall with Different stiffness with Outer Central Opening" by Mohammad H. Jinya, V. R. Patel ,Volume: 03 Issue: 06, Jun-2014, http://www.ijret.org.

[2].. "Dynamic Analysis of Infills on R.C FramedStructures" by Manju G, Volume 3, Issue 9, September 2014, www.ijirset.com.

[3].. "Seismic Performance of Friction Pendulum Bearing by Considering Storey Drift and Lateral Displacement" by Vindhya Bhagavan, G.V Sowjanya, Chethan Kumar B, Sandeep Kumar D.S, Volume: 03 Issue: 08 | Aug2014,www.ijret.org.

[4].. "The Influence of Infill Walls on RC Frames under Seismic Excitation" by Lului,Ziyan Wu, November 2014, volume 2, issue 4, http://www.ivypub.org.

[5].. "Influence of Masonry Infill Walls On Seismic Performance of RC Framed Structures a Comparision of AAC andConventional Brick Infill" by Vikas P. Jadhao, Prakash S. Pajgade, Volume-2, Issue-4, April 2013, IJEAT. [6].. "Earthquake Analysis of High Rise Building with and Without In filled Walls" by Wakchaure M.R, Ped S. P, Volume 2, Issue 2, August 2012, www.ijeit.org.

[7].. "Equivalent Strut Width for Partial Infilled Frames" by Prachand Man Pradhan, DOI: 10.5923/j.jce.20120205.03, Journal of Civil Engineering Research 2012, 2(5): 42-48.

[8].. "Seismic Analysis of RC Frame Structure with and without Masonry InfillWalls" by Haroon RasheedTamboli and Umesh.N.Karadi , Volume.3 / Issue 14/ October2012, www.tnsroindia.org.in.

[9].. E-tabs version 2013 manual

[10].. IS1893 (part 1):2002 "Criteria for Earthquake Resistant Design of Structures"- General Provisions and Buildings (fifth revision).

[11].. IS 875 (part 3):1987 "Code of practice for design loads (other than Earthquake loads) for Buildings and Structures "- Wind loads (second revision).

[12].. Proposed Draft Provisions and Commentary on Indian seismic code IS 1893 (part1) by Dr. Sudhir K Jain and Dr. C V R Murthy - IITK-GSDMA-EQ15-V3.0.

\section{BIOGRAPHIES}

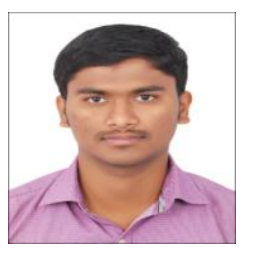

Chidananda $\mathrm{H} \mathrm{R}$ is a M.tech Disseration student doing his thesis under the guidance of Mr. Raghu $\mathrm{K}$ from Visveswaraya Technological University, Belgaum

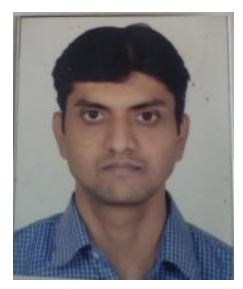

He is Mr. K Raghu Assistant Professor, Department of civil engineering, S J C Institute of Technology, Chickaballapur. $\mathrm{He}$ is also a structural Design consultant. He has more than 6 years of experience in the field of structural and civil engineering. He has more than 3 years of teaching Experience. He has designed various projects which includes steel structures and High rise buildings. 
He DR. G Narayana, Professor and

Head of Department, Department Of

Civil Engineering, S J C Institute of

Technology, Chickaballapur. He has a

wide experience in teaching and research

in the field of Structural engineering. He

is also a structural designed consultant for many projects. 